Ekonomia - Wroclaw Economic Review 26/1 (2020)

Acta Universitatis Wratislaviensis

No 3991

https://doi.org/10.19195/2658-1310.26.1.4

Klaudia Pawlak

ORCID: 0000-0001-9584-9127

Uniwersytet Wrocławski

282706@uwr.edu.pl

\title{
Determinanty kształtowania polityki opakowań w Polsce i na świecie
}

\author{
Artykuł nadesłany: 27.11.2019; artykuł zaakceptowany: 17.03.2020 \\ Kody klasyfikacji JEL: Q500, Q530, Q550, Q570, Q580
}

Keywords: waste, package, zero waste, disposable products, plastic, environment

\section{Abstract \\ Determinants of shaping packaging policy in Poland and in the world}

The packaging market is one of the largest consumers of plastics both in Poland and worldwide. This constantly growing industry generates huge amounts of packaging waste, and additionally disposable products, that storage has a negative impact on the environment. The aim of the article is to present ways of opposing a packaging policy that is destructive to the environment. This work was based on literature, legal regulations and secondary research on the economy in the field of packaging and disposable products.

\section{Wstęp}

$\mathrm{Na}$ świecie następuje globalne ocieplenie, wskutek czego wymiera coraz więcej gatunków zwierząt, a wody lądowe i powietrze stają się coraz bardziej zanieczyszczone. Wszystko to jest wynikiem ingerencji człowieka w środowisko naturalne. Oczywiście nie zawsze jest to postępowanie celowe, niektóre konsekwencje pojawiają się dopiero wiele lat później i często niemożliwe jest przewidzenie, do jak bardzo niekorzystnych skutków może dojść w przyszłości. Aktualnie jednym z najpoważniejszych problemów na świecie jest kwestia odpadów. Krajobraz $\mathrm{z}$ wszechobecnymi hałdami śmieci to dziś codzienność w wielu miejscach globu, a jak wiadomo, znaczną większość śmieci tworzą odpady opakowaniowe. Więk- 
szość z nich jest wytwarzana $\mathrm{z}$ bardzo wolno lub praktycznie nierozkładających się tworzyw sztucznych, popularnie zwanych plastikami. Co roku każdy człowiek generuje wiele kilogramów plastikowych odpadów opakowaniowych, które trzeba gdzieś składować, ponieważ tylko bardzo mała część z nich jest poddawana recyklingowi. Zagadnienie to można poszerzyć o bardzo często w życiu człowieka stosowane przedmioty jednorazowego użytku, które najczęściej również są produkowane z nieprzyjaznych dla środowiska tworzyw sztucznych. Naprzeciw problemom dotyczącym plastiku wychodzi coraz więcej uregulowań prawnych narzucających na mieszkańców poszczególnych państw obostrzenia w temacie produkcji, użytkowania czy składowania odpadów. Walka z zaśmiecaniem planety powinna zatem koncentrować się w głównej mierze na redukcji produkcji opakowań plastikowych oraz przedmiotów przeznaczonych do jednokrotnego użycia. Uzupełniająco poszczególne kraje powinny edukować swoje narody i uświadamiać im, że odpad to też swego rodzaju surowiec, który dzięki recyklingowi może otrzymać nowe życie.

Celem artykułu jest przedstawienie sposobów walki z destrukcyjną dla środowiska polityką opakowań.

\section{Opakowania i produkty jednorazowe}

Rocznie w Polsce wykorzystywanych jest 3,5 miliona ton tworzyw sztucznych, przy czym trzecia część tej wartości, czyli prawie 1,2 miliona ton, zostaje wykorzystana do produkcji opakowań. Niestety ludzie nie są jeszcze świadomi, do jakiej sytuacji naszego środowiska naturalnego dążą takim zachowaniem i tylko $40 \%$ opakowań w polskich gospodarstwach domowych zostaje poddanych recyklingowi.

\subsection{Opakowania - definicja}

Opakowanie jest kategorią trudną do jednoznacznego zdefiniowania, chociażby ze względu na mnogość funkcji, które pełni. Próby definiowania tego pojęcia są nieustannie podejmowane przez wielu autorów literatury dotyczącej samego produktu, a często również istoty marketingu. $\mathrm{W}$ polskim prawodawstwie zgodnie z ustawą z dnia 13 czerwca 2013 roku o gospodarce opakowaniami i odpadami opakowaniowymi opakowaniem nazywa się „wyrób, w tym wyrób bezzwrotny, wykonany z jakiegokolwiek materiału, przeznaczony do przechowywania, ochrony, przewozu, dostarczania lub prezentacji produktów, od surowców do towarów przetworzonych" (Ustawa, 2013). Wyjaśnienie to unaocznia co najmniej podstawowe funkcje spełniane przez opakowania. Ciekawą, a dodatkowo bardzo prostą do zrozumienia definicję prezentuje J.H. Briston, twierdząc, że opakowanie „musi zabezpieczyć to, co sprzedaje i sprzedawać to, co zabezpiecza" (Hales, 1999). Przystępując do omawiania tematu opakowań, należy jednak poszerzyć wiedzę 
na ten temat. Po przestudiowaniu wielu pozycji literaturowych można stwierdzić, że opakowanie jest to dodatkowa zewnętrzna warstwa jakiegoś materiału w odniesieniu do produktu, którego wytwarzaniem, transportem i sprzedażą zajmuje się dane przedsiębiorstwo. Warstwa ta realizuje takie funkcje, jak: ochrona towaru przed czynnikami zewnętrznymi, przechowywanie, umożliwienie lub ułatwienie transportu, przyciągnięcie uwagi klienta $\mathrm{z}$ konkretnej grupy docelowej, poinformowanie go o zawartości (co to za produkt, z czego jest zrobiony, dla kogo jest przeznaczony itp.), użycie jako nośnika znaków informacyjnych, cen czy kodów kreskowych. Dodatkowo opakowanie powinno być zoptymalizowane pod względem materiałów, z których zostało wykonane, gabarytów oraz masy, jak również pod względem kosztów. Powinno zachęcić klienta do zakupu, a po zakupie zapewnić łatwość i komfort użytkowania, na przykład poprzez możliwość wielokrotnego otwierania i zamykania czy możliwość dozowania produktu. Opakowanie jest to zatem jeden z najważniejszych elementów produktu, a zarazem jeden z najistotniejszych instrumentów marketingowych, zwłaszcza w czasach ekologicznego boomu, w których bardzo często zdarza się, że konsumenci świadomie wybierają dobra, których opakowania są przyjazne dla środowiska. To właśnie ten ekologiczny aspekt będzie istotą niniejszego artykułu.

\subsection{Podział opakowań}

W literaturze przedmiotu można znaleźć wiele różnych podziałów opakowań. Najczęstszymi kryteriami klasyfikacji opakowań są:

- rodzaj materiału wykorzystanego do wyprodukowania opakowania opakowania szklane, papierowe, drewniane, z tworzyw sztucznych, metalowe itp., wyjątkiem są opakowania wielowarstwowe, w których poszczególne warstwy wykonane są z odrębnych materiałów;

— ilość produktów w opakowaniu — opakowania jednostkowe, grupowe czy zbiorcze;

— rodzaj konstrukcji — butelki, beczki, pudełka, kartony, puszki, skrzynki, worki itp.;

— częstość użytkowania — jednorazowe i wielorazowe.

W tym miejscu warto zwrócić uwagę na rzadko spotykane w literaturze, ale istotne z punktu widzenia niniejszego artykułu, rozróżnienie opakowań na biodegradowalne, przyjazne dla środowiska oraz nieprzyjazne dla środowiska. Opakowanie biodegradowalne to pojęcie, które swoją nazwę zawdzięcza terminowi „biodegradacja” oznaczającemu „biochemiczny rozkład związków organicznych zachodzący przy udziale mikroorganizmów z wytworzeniem dwutlenku węgla, wody i innych związków mineralnych" (Biodegradacja, 2019). Oznacza to, że opakowanie zostało wytworzone z materiału pochodzenia naturalnego, które po wykorzystaniu przez konsumenta, przy założeniu odpowiednich warunków, naturalnie się rozkłada w okresie zaledwie do kilku lat. Do 
produkcji takich opakowań używa się na przykład bioplastiku wytwarzanego z surowców naturalnych, ale zachowującego cechy tworzyw sztucznych. Opakowania przyjazne dla środowiska to natomiast wszystkie te opakowania, które pozwalają ponownie je zużytkować, czyli innymi słowy poddać recyklingowi. Tego typu opakowania mają naprawdę duży potencjał, ponieważ można je wykorzystywać wielokrotnie. Materiałami, z których wytwarza się opakowania przyjazne dla środowiska, są przede wszystkim szkło i papier. Ostatnią kategorię tworzą opakowania nieprzyjazne dla środowiska i są to wszystkie pozostałe opakowania, które z jakiegoś względu wywierają destrukcyjny wpływ na środowisko. Do materiałów, z których produkuje się takie opakowania, zalicza się przede wszystkim tworzywa sztuczne.

\subsection{Produkty jednorazowego użytku}

Dziś wielką wagę w rozwoju współczesnej gospodarki odgrywają produkty jednorazowego użytku, które najczęściej wytwarzane są z plastiku i nie podlegają procesowi recyklingu ani degradacji. Po pojedynczym użyciu trafiają one do koszy na śmieci. Według dyrektywy Unii Europejskiej ,produkt jednorazowego użytku z tworzyw sztucznych oznacza produkt, który jest w całości lub częściowo wykonany z tworzyw sztucznych i który nie został przeznaczony, zaprojektowany ani wprowadzony do obrotu tak, aby osiągnąć w ramach okresu żywotności wielokrotną rotację poprzez zwrócenie go do producenta w celu powtórnego napełnienia lub ponownego użycia do tego samego celu, do którego był pierwotnie przeznaczony" (Parlament Europejski i Rada UE, 2019).

Najczęściej spotykane jest wyliczenie popularnych przedmiotów jednorazowych, które już dziś przedsiębiorcy mogą wyprodukować metodami alternatywnymi. Należą do nich: plastikowe sztućce (widelce, noże i łyżki), talerze, pojemniki na żywność z restauracji typu fast food, słomki, mieszadełka do napojów, styropianowe kubeczki, cienkie foliowe torebki, patyczki higieniczne oraz patyczki do balonów. Według komunikatu prasowego Komisji Europejskiej z 28 maja 2018 roku rzeczy te wraz z porzuconymi narzędziami połowowymi stanowią aż $70 \%$ wszystkich odpadów morskich. Niezwykle intrygujące jest również stwierdzenie, że „każdego roku do oceanu trafia 8 milionów ton plastiku, w tym plastikowych toreb. Według prognoz Programu Środowiskowego ONZ przy zachowaniu takiego tempa do 2050 roku w oceanach będzie więcej plastiku niż ryb" (PAP, 2019). Taka wizja przyszłości jest zatrważająca, w związku z tym nie tylko pojedyncze osoby, ale i całe państwa, a nawet organizacje ponadnarodowe starają się wprowadzać w życie jak najwięcej działań dążących do powstrzymania dalszego zaśmiecania wód. Osobnym tematem, aczkolwiek pokrewnym, jest kwestia odpadów pochodzących z wyrobów tytoniowych, a w szczególności filtrów z papierosów, w których bardzo często 
zawarty jest również plastik. Niezwykle niepokojąca jest informacja zawarta w rezolucji przyjętej przez Komisję do spraw Środowiska i Zdrowia Publicznego Parlamentu Europejskiego: ,jeden niedopałek zawierający filtr z dodatkiem plastiku może zanieczyścić od 500 do nawet 1000 litrów wody, jeśli trafi do morza, oceanu lub jeziora" (Strzałkowski, 2018).

\subsection{Tworzywa sztuczne jako problem na skalę światową}

Historia tworzyw sztucznych sięga drugiej połowy XIX wieku, kiedy to zapoczątkowano stopniowe wprowadzanie do produkcji nowych materiałów — od nitrocelulozy po poliester. Z czasem producenci przeróżnych towarów dostrzegli w tworzywach sztucznych potencjał i zaczęli je wykorzystywać masowo do produkcji towarów oraz ich elementów. Tworzywa sztuczne momentalnie zawładnęły rynkiem opakowań. Plastik ma wiele użytecznych cech, takich jak odporność na działanie czynników zewnętrznych, między innymi substancji chemicznych, nieprzewodnictwo elektryczne oraz łatwość obróbki, możliwość nadawania mu często skomplikowanych kształtów czy zabarwiania go na wiele kolorów. Rynek opakowań według badań Deloitte konsumuje ponad 30\% wytwarzanego w Polsce plastiku i jest to największy konsument tworzyw sztucznych w naszym kraju. Ilość plastiku zużywanego w Polsce do produkcji opakowań z roku na rok jest coraz większa; w latach 2013-2017 liczba ta zwiększyła się aż o 20\% (Deloitte Polska, 2019). Zgodnie z danymi Eurostatu w 2016 roku na jednego mieszkańca Unii Europejskiej przypadało $170 \mathrm{~kg}$ odpadów opakowaniowych, $55 \mathrm{~kg}$ w Chorwacji, ale aż $221 \mathrm{~kg}$ w Niemczech.

Plastiki należą do surowców trudno rozkładalnych, w zależności od rodzaju tworzywa sztucznego rozkładają się one od 100 do 1000 lat. W odniesieniu do znacznej części plastikowych odpadów istnieje możliwość ich ponownego użycia zwana recyklingiem. Niewielu mieszkańców Unii Europejskiej poczuwa się do segregacji śmieci. Dlatego nie wykorzystuje się pełnego potencjału recyklingu. Dane za rok 2017 w Unii Europejskiej przedstawia rysunek 1.

Coraz częściej poruszana tematyka ochrony środowiska spowodowała, że konsumenci zaczęli wymagać od producentów minimalizowania negatywnego wpływu działalności przedsiębiorstw na środowisko — zarówno bezpośredniego (wylewania zanieczyszczeń do zbiorników wodnych, wypuszczania do atmosfery szkodliwych gazów), jak i pośredniego (używania do produkcji materiałów, które po zakończeniu swojej przydatności dla konsumenta rozkładają się w środowisku przez setki, a nawet tysiące lat). Dlatego w celu sprostania wymaganiom klientów przedsiębiorcy ciągle wprowadzają nowe rozwiązania, dzięki którym można zmniejszyć ilość plastikowych odpadów, czyli plastikowych opakowań towarów zużytych przez konsumentów oraz produktów jednorazowego użytku. 
Wskaźnik recyklingu odpadów z tworzyw sztucznych w krajach członkowskich Unii Europejskiej w 2017 roku

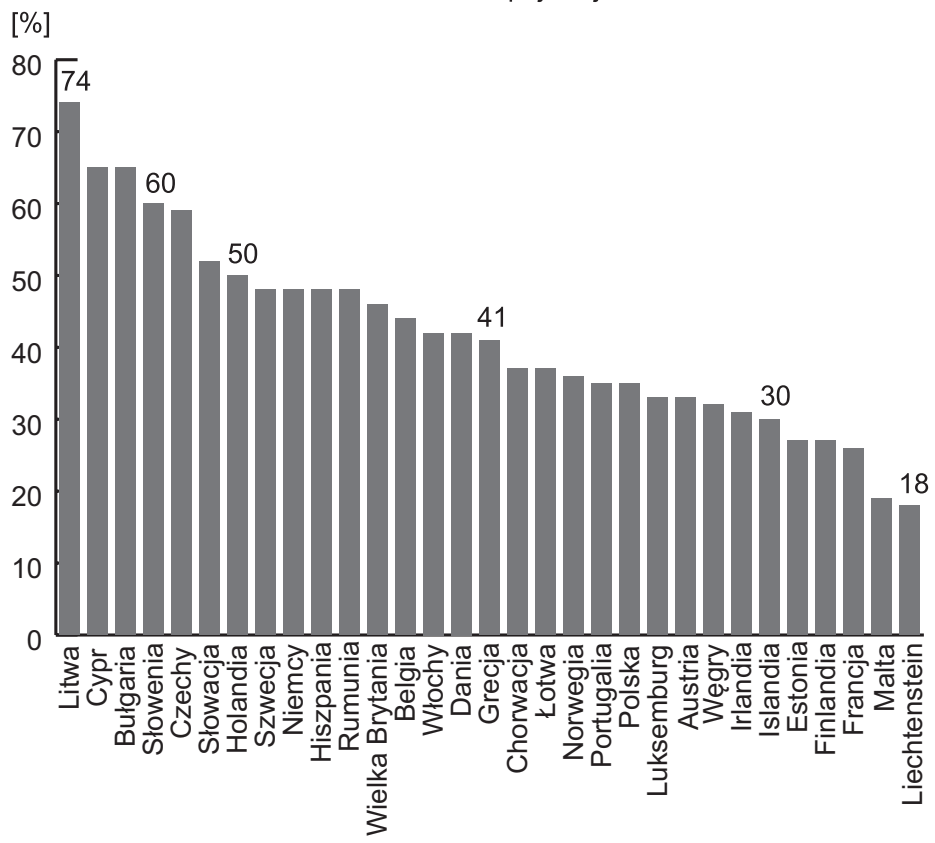

Rysunek 1. Wskaźnik recyklingu odpadów z tworzyw sztucznych w krajach członkowskich Unii Europejskiej w 2017 roku [\%] 2019).

Źródło: https://ec.europa.eu/eurostat/web/products-eurostat-news/-/DDN-20191105-2 (dostęp: 16.07.

\section{Sposoby radzenia sobie z problemem tworzyw sztucznych}

Problem plastiku na świecie jest tak często poruszany, że powstało wiele metod ograniczania użytkowania tworzyw sztucznych w produkcji. Należy do nich zaliczyć regulacje prawne, czyli państwowe lub ponadnarodowe próby poradzenia sobie z tym problemem, akcje społeczne, dzięki którym edukuje się społeczeństwo, oraz wszelkie alternatywy wytworzone w celu zastąpienia przedmiotów plastikowych.

\subsection{Regulacje prawne}

Obecnie duży nacisk kładzie się na zredukowanie ilości plastiku wykorzystywanego w gospodarce. Kwestia ta została usankcjonowana prawnie dyrektywą Parlamentu Europejskiego i Rady (UE) 2019/904 z dnia 5 czerwca 2019 roku w sprawie zmniejszenia wpływu niektórych produktów z tworzyw sztucznych na środowisko (dalej: dyrektywa). Akt ten ma na celu przeciwdziałanie negatywne- 
mu oddziaływaniu niektórych produktów z tworzyw sztucznych na środowisko naturalne ze szczególnym naciskiem na środowisko wodne, a w konsekwencji na zdrowie ludzi. Dyrektywa ta odnosi się do produktów jednorazowego użytku, wykonanych w tworzyw sztucznych lub z oksydegradowalnych tworzyw sztucznych oraz do zawierających tworzywa sztuczne narzędzi połowowych. Na podstawie art. 4 tej regulacji państwa członkowskie obligują się do zmniejszenia ilości stosowanych na rynku kubków na napoje, w tym ich przykrywek, oraz pojemników na żywność, do przechowywania dań gotowych czy typu fast food. Mają one do dyspozycji dwie główne drogi do realizacji tego postanowienia, a mianowicie albo zastąpienie tych produktów alternatywnymi, lepszymi dla środowiska, albo uniemożliwienie bezpłatnego wydania tych produktów klientowi końcowemu.

Do kolejnej grupy przedmiotów, tym razem objętych nie zmniejszeniem ilości, lecz zakazem wprowadzania do obrotu na rynek, zawartym w art. 5 dyrektywy należą: patyczki higieniczne, sztućce obejmujące noże, łyżki, widelce oraz pałeczki, talerze, kubki na napoje wykonane z polistyrenu ekspandowanego, słomki, mieszadełka, pojemniki na napoje oraz pojemniki na żywność wykonane z polistyrenu ekspandowanego i patyczki do balonów. Zgodnie z art. 6 do obrotu w państwach członkowskich mogą zostać dopuszczone jedynie takie pojemniki na napoje do 3 litrów, do których podczas użytkowania produktu przymocowane pozostaną ich zakrętki lub wieczka wykonane również z tworzyw sztucznych. Kraje Unii Europejskiej, również na podstawie art. 6 dyrektywy, w stosunku do butelek na napoje do 3 litrów oraz ich zakrętek, których głównym składnikiem jest politereftalan etylenu (PET), mają za zadanie do 2025 roku zapewnić, aby co najmniej 25\% tworzyw sztucznych, z których są produkowane, pochodziło z recyklingu, a następnie do 2030 roku podnieść tę wartość do 30\%. Zgodnie z art. 7 dyrektywy takie produkty, jak: kubki na napoje, wyroby tytoniowe z filtrami, chusteczki nawilżane, podpaski higieniczne, aplikatory do tamponów oraz tampony będą mogły być wprowadzane do obrotu jedynie po umieszczeniu na opakowaniu lub bezpośrednio na produkcie specjalnych oznakowań. Będą one informowały konsumentów o odpowiedniej metodzie gospodarowania odpadami, jak również o zawartości tworzyw sztucznych i złym wpływie zaśmiecania na środowisko naturalne. Dodatkowo państwa członkowskie powinny podejmować kroki w celu informowania konsumentów o zawartości tworzyw sztucznych w danym produkcie oraz konsekwencjach użytkowania i nieodpowiedniego pozbywania się danego produktu, tak aby uświadomić im problem odpadów i ich oddziaływanie na środowisko, co przyczyni się do odpowiedzialnego zachowania klientów. Komisja Europejska szacuje, że dzięki tym przepisom uda się uniknąć szkód środowiskowych, których koszt do 2030 roku stanowiłby równowartość 22 mld euro.

Nie tylko w Europie podejmowane są prawne kroki do walki z plastikiem. Ostatnimi czasy bardzo głośna była sprawa Indii, których zarówno ląd, jak i woda są zanieczyszczone w zatrważającym stopniu. Państwo nie potrafiło sobie poradzić z takim stanem rzeczy, aż w październiku 2019 roku rząd indyjski wpro- 
wadził całkowity zakaz sprzedaży plastikowych przedmiotów jednorazowych. Jest to niezwykle radykalny krok, którego rezultaty podlegają dyskusji. Z jednej strony realnie ograniczy znacznie to wykorzystywanie przez ludzi plastiku, chociaż pojawia się pytanie, czy samo ograniczenie używania go bez zwiększenia świadomości ludzi i segregacji odpadów da wymierne skutki. $Z$ drugiej zaś strony zakaz ten może dać negatywne konsekwencje odnośnie do pracowników firm produkujących tego typu produkty oraz ich rodzin, ponieważ stracą oni źródło utrzymania, oraz właścicieli tych firm, którzy w dużej mierze zadłużali się, żeby zakupić bardzo drogie maszyny do produkcji. Decyzja rządu zaskoczyła ludność, nie dając przy tym możliwości zabezpieczenia majątku czy przebranżowienia.

Kolejnym ciekawym przykładem kraju stosującego regulacje prawne jest Kenia, w której w sierpniu 2017 roku wprowadzono zakaz produkcji, sprzedaży i używania torebek foliowych. Zakaz ten jest niezwykle restrykcyjny, ponieważ za jego nieprzestrzeganie grozi kara grzywny aż do równowartości 38 tysięcy dolarów lub do czterech lat więzienia. Zakaz ten obowiązuje nie tylko Kenijczyków, ale również turystów odwiedzających ten kraj. Od dnia jego wprowadzenia w sklepach można się zaopatrzyć w materiałowe torby wielokrotnego użytku. Co ciekawe, nie tylko Kenia wprowadziła ten zakaz — dane dotyczącego tego tematu na marzec 2019 roku przedstawia rysunek 2.

\section{Zakaz używania plastikowych toreb}

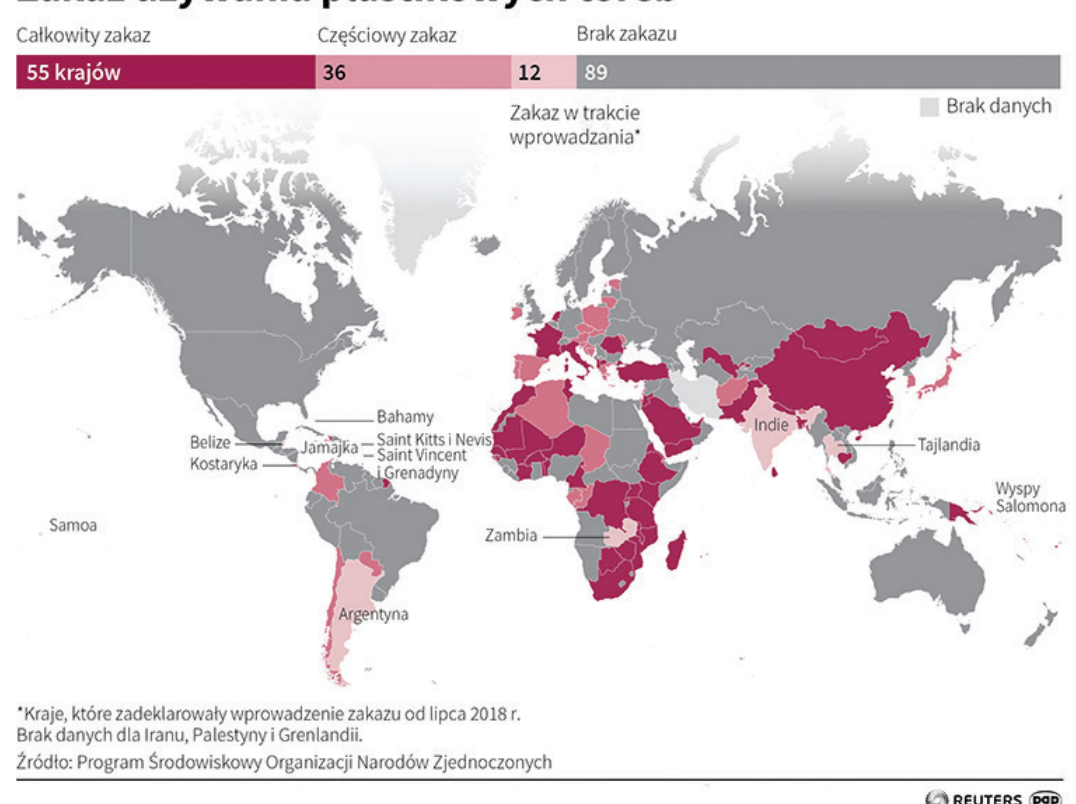

Rysunek 2. Kraje, które wprowadziły zakaz używania plastikowych toreb w 2019 roku

Źródło: https://www.tvp.info/41621193/co-roku-do-oceanu-trafia-8-milionow-ton-plastiku-za-30-lat-bedzie-go-wiecej-niz-ryb (dostęp: 12.08.2019).

Ekonomia - Wroclaw Economic Review 26/1, 2020

(C) for this edition by CNS 


\subsection{Akcje społeczne}

Opakowania przyjazne środowisku są podstawą propagowanej przez ministerstwo środowiska oraz organizację World Wide Fund for Nature (dalej WWF) gospodarki o obiegu zamkniętym. W codziennym życiu bardzo często spotykamy się z sytuacją, w której nabywamy jakiś produkt, zużywamy go, a następnie wyrzucamy do śmietnika. Naprzeciw takiemu zachowaniu wychodzi właśnie ta koncepcja, której idea zakłada, że zamiast wyrzucić dany produkt, damy mu „nowe życie" przez recykling, naprawę, wymianę, odsprzedaż itp. Dzięki temu wprowadzimy go do obiegu ponownie, będziemy z niego długo korzystać, a przy okazji powstrzymamy się od nadmiernego wytwarzania odpadów.

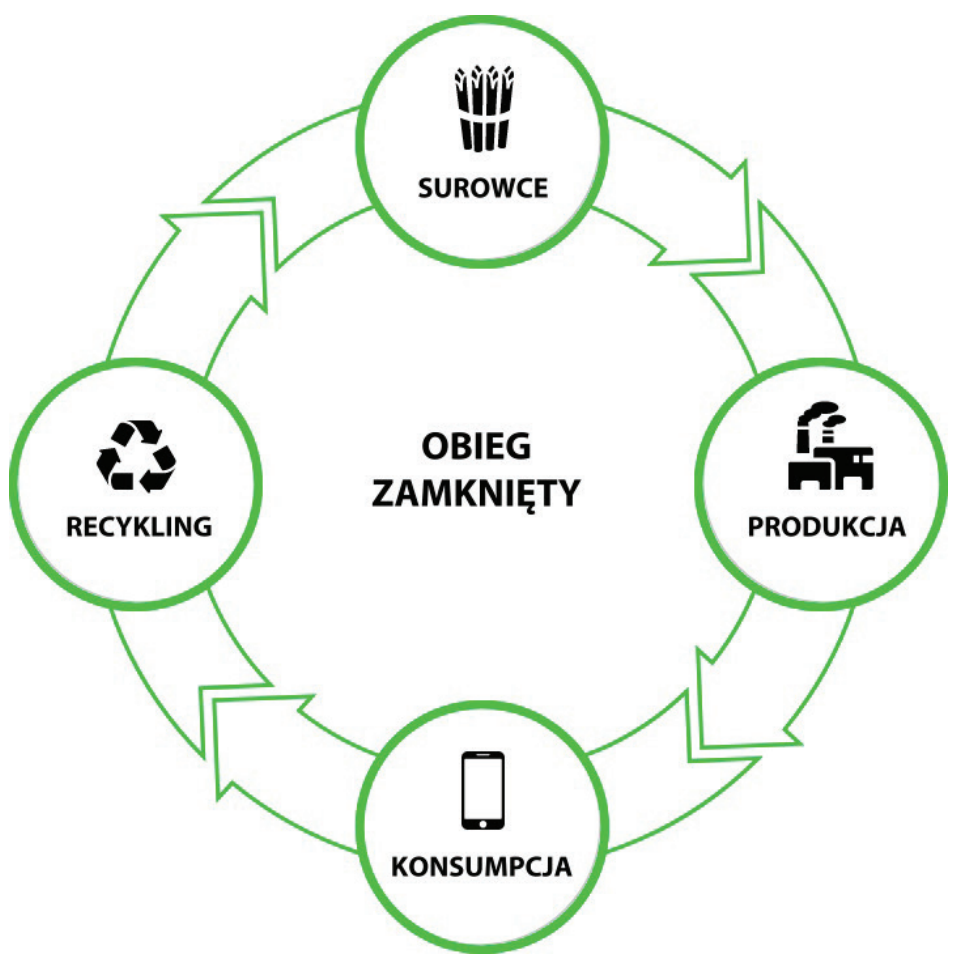

Rysunek 3. Gospodarka o obiegu zamkniętym

Źródło: https://www.wwf.pl/ekonsumpcja/gospodarka-o-obiegu-zamknietym (dostęp: 21.09.2019).

WWF promuje również dodatkową koncepcję pomagającą ograniczyć liczbę generowanych odpadów, a mianowicie zasadę $3 \mathrm{R}$ - „Reduce, Reuse, Recycle”. Najprościej można ująć to hasło tak: „reduce” (ograniczaj) dotyczy kupowania jedynie towarów potrzebnych do życia i przy okazji bez zbędnych opakowań, „reuse” (ponownie używaj) to wykorzystanie zużytego produktu do nowego celu, choć nie zawsze oczywistego, a „recycle” (utylizuj) odnosi się do segregacji śmieci i recyklingu. 
Całość takich działań, jak obieg zamknięty czy zasada 3R, zawiera się w koncepcji zero waste, co można przetłumaczyć na polski jako „bez śmieci” czy „bez marnowania". Jej ideą jest prowadzenie takiego stylu życia, w którym zmierzamy do minimalizowania generowania odpadów. Niewiele osób stosuje tę zasadę we wszystkich swoich codziennych czynnościach, ale mnogość zachowań wspierających tę inicjatywę pozwala każdemu na chociażby minimalne polepszenie stanu środowiska naturalnego. Samo noszenie przy sobie wielorazowej torby na zakupy zmiast kupowania w każdym sklepie kilku toreb foliowych jest małym kroczkiem do osiągnięcia wielkiego celu. Natomiast ludzie przyzwyczajeni do komfortu na pewno bardzo niechętnie zaczęliby nosić z sobą nie tylko torbę, ale również butelkę na mleko czy słoiki, które można ponownie napełnić. Koncepcja zero waste rozbudowuje zasadę 3R, w niektórych przypadkach nawet do 7R. Dodatkowe założenia to: „refuse” (odmawiaj) obejmujące wzbranianie się od używania przedmiotów jednokrotnego użytku czy przyjmowania gazetek lub ulotek reklamowych, „rot” (kompostuj) dotyczące używania przedmiotów kompostowalnych oraz kompostowania odpadków organicznych i uzyskiwania z nich naturalnych nawozów, „repair” (naprawiaj) odnoszące się oczywiście do naprawy przedmiotów, które mamy, zmiast kupowania nowych, oraz „remember” (pamiętaj), czyli miej świadomość, że twoje codzienne wybory mają wpływ na środowisko naturalne oraz pamiętaj o zasadach życia w stylu zero waste.

Od 2018 roku w Polsce bardzo głośną jest kampania społeczna „Tu pijesz bez słomki”, w której słomka jest symbolem walki o lepsze jutro. Wielu celebrytów nawołuje w niej do porzucenia nawyku picia przez słomkę oraz serwowania napojów bez słomki w pubach, barach czy restauracjach. Według serwisu noizz.pl codziennie w Polsce zużywa się 3 miliony plastikowych słomek, a w 2017 roku znajdowały się one na siódmym miejscu listy śmieci najczęściej zbieranych na plażach. W dobie dzisiejszej technologii jesteśmy jednak w stanie wyprodukować słomki z wielu innych przyjaznych dla środowiska materiałów, dzięki czemu fanaberia picia przez słomkę nie musi całkowicie zniknąć. Tak naprawdę wystarczy jedynie wymienić plastikową słomkę na słomkę papierową, metalową lub nawet taką wytworzoną z pszenicy czy awokado. Słomka wykonana z awokado — to brzmi intrygująco, ale firma Naturally Chic dostrzegła potencjał w pestkach awokado: produkcję prowadzi w Meksyku, korzystając z odpadów rolniczych powstałych przy produkcji guacamole. Słomka ta jest bardzo twarda i trwała, co umożliwia korzystanie z niej bez względu na rodzaj i temperaturę napojów. W normalnych warunkach rozkłada się ona około 180-240 dni.

\subsection{Alternatywy}

Najbardziej logicznym sposobem na znaczące zmniejszenie wytwarzanych odpadów opakowaniowych jest produkcja towarów niezawierających zbędnych opakowań, jak na przykład szampon w kostce zawinięty jedynie w papierowe opa- 
kowanie przyjazne środowisku. Biorąc pod uwagę, jak często myjemy włosy i ile wyrzucamy rocznie plastikowych butelek po szamponie, należy uznać pomysł na szampon w kostce za niezwykle obiecujący. Wiadomo, że ludzie przyzwyczajeni do płynu mogą mieć spore obiekcje przed kupowaniem tego kosmetyku w takiej formie. Można jednak założyć, że jak dotąd niewielkie grono ludzi dowiedziało się o istnieniu takiego rozwiązania.

Na rynku kosmetycznym coraz więcej firm wprowadza organiczne kosmetyki. Tylko czy misja producenta organicznych kosmetyków jest spełniona w momencie, w którym sprzedaje on swoje produkty w kompletnie nieprzyjaznych środowisku opakowaniach? Nie do końca, właśnie dlatego przedsiębiorstwa te poszukują biodegradowalnych rozwiązań, dzięki którym kosmetyk będzie dobry dla człowieka, jego zdrowia oraz planety. Na przykład fińska firma Sulapac opatentowała projekt materiału z różnych biomateriałów i odnawialnego naturalnego drewna. Stworzyła ona proste opakowania biodegradowalne na kosmetyki, cechujące się odpornością na wodę i oleje. Co więcej, rozwiązanie to eliminuje problem przenikania tlenu do produktu. Materiał ten dodatkowo jest wolny od mikroplastiku, co oznacza, że po jego rozłożeniu nie zostają po nim żadne, nawet najmniejsze drobinki. Zauważając potencjał firmy Sulapac, inwestycji w nią podjęła się luksusowa marka Chanel.

Innowacją rewolucjonizującą rynek wody butelkowanej jest wymyślona przez start-up Skipping Rocks Lab jadalna kulka wody, którą nazwano Ooho. Jest to produkt przypominający przezroczystą galaretkę. W środku kapsułki znajduje się zwykła woda mineralna - aby się jej napić wystarczy ściągnąć osłonkę i delikatnie ścisnąć kulkę. Wodę można zastąpić jakimkolwiek innym płynem. Ooho wytwarzane jest z ekstraktu brązowych alg i chlorku wapnia, jest zatem w 100\% biodegradowalne oraz w pełni jadalne. Niezużyta globulka rozłoży się po mniej więcej 5 miesiącach. „Szacuje się, że w samych tylko Stanach Zjednoczonych rocznie na wysypiska śmieci trafia 35 miliardów plastikowych butelek, gdyby chociaż część z nich dało się zastąpić ekologicznymi wodorostami, byłoby wspaniale" (Jadalne..., 2017). Dodatkowo produkcja Ooho jest niezwykle tania i co najważniejsze znacznie tańsza od produkcji plastikowych butelek.

Coraz częściej na rynku uwidacznia się inicjatywa wielkich marek, które ograniczają zużycie plastiku i wprowadzają wiele alternatyw. Ciekawym przykładem takiego przedsiębiorstwa jest znany na całym świecie koncern Coca-Cola, który wyprodukował butelkę z plastiku wyłowionego z oceanów. Wraz z grupą naukowców wykreował on technologię, dzięki której surowce niskiej jakości mogą zostać przemienione w materiał nadający się do pakowania żywności i w najbliższym czasie planują wprowadzić te butelki na dużą skalę.

Kolejną metodą ograniczenia ilości odpadów jest tworzenie produktów wielorazowych zastępujących używane na co dzień towary jednorazowe. Dobrym przykładem jest polska firma Torbacze, która rozpoczęła działalność od wprowadzenia na rynek wielorazowych ekologicznych worków wykonanych w 100\% 
z siatki bawełnianej. Worki te są dobrym zamiennikiem woreczków plastikowych czy toreb foliowych, zwłaszcza gdy przyjrzymy się cyfrom i dowiemy się, że „statystyczny Polak w ciągu roku przynosi ze sklepu 500 takich toreb, których używa przez kilka minut, a które będą się rozkładać przez kilkaset lat" (Bellon, 2018).

Następnym przykładem firmy wprowadzającej ekologiczne innowacje na rynek jest firma Adidas, która ogłosiła, że do końca 2024 roku zamiast plastiku, którego nie będzie można potem przetworzyć, do produkcji swoich towarów będzie stosować jedynie plastik pochodzący z recyklingu. Postanowienie to tyczy się zarówno linii produkcyjnej, jak i wszelkich biur czy punktów sprzedaży. Ponadto oceniono, że zapoczątkowując zmiany już w tym roku, przez najbliższy rok firma zużyje o 40 ton mniej plastiku, niż zrobiłaby to przy dotychczasowych założeniach produkcji.

Istnieje też na rynku wiele firm, które zaczęły się zastanawiać nad możliwością wykorzystania odpadów produkcyjnych. Dobrym ich przedstawicielem jest polska firma Biotrem, której założyciel znalazł bardzo korzystny sposób spożytkowania otrąb będących odpadami w młynach. Opatentował on technologię, która obejmuje dodanie wody do otrąb pszennych, a następnie wytłoczenie naczyń $\mathrm{w}$ odpowiedniej temperaturze za pomocą wytłaczarki. Taki produkt jest $\mathrm{w}$ pełni biodegradowalny i może być używany do serwowania gotowych dań bez względu na temperaturę czy konsystencję, a dodatkowo do podgrzewania i pieczenia w piekarnikach. Co ciekawe, takie talerze można bez problemu zjeść po skończeniu posiłku. Warto również wspomnieć, że produkcja tego typu naczyń jest efektywna - jak czytamy na stronie producenta ,z 1 tony naturalnych otrąb spożywczych, będących produktem ubocznym w procesie produkcji mąki, możemy wytworzyć do 10 tysięcy sztuk naczyń" (Tworzymy..., 2016).

Naczynia jednorazowe nie są wytwarzane jedynie $\mathrm{z}$ otrąb pszennych — na rynku istnieje materiał równie przyjazny dla środowiska, jakim są liście palmowe. Występuje wiele różnych technologii wykonywania naczyń z tego materiału. W firmie Farmbites używane są tylko białe liście, które po swobodnym opadnięciu z drzewa są zbierane i rozdzielane według ich jakości. W kolejnym etapie najlepsze liście są czyszczone, prasowane na gorąco, w pełni sterylizowane i naturalnie polerowane bez użycia środków chemicznych i barwników. Produkt ten jest niezwykle wytrzymały, można go używać zarówno w niskich, jak i wysokich temperaturach, a nawet w piekarniku. Naczynia te są pozbawione wszelkich chemikaliów, lakierów czy barwników, co sprawia, że nie wpływają na smak jedzenia. Dla porównania firma Beleaf, produkująca również tego typu naczynia jednorazowe, używa tylko zielonych liści, a jej talerz składa się z trzech warstw: górna i dolna wykonane są z liści zszytych włóknami z tych samych liści. Środkową warstwą jest papier również wykonany z liści. Tak wytworzone naczynie jest biodegradowalne i rozkłada się w ciągu 28 dni.

Następnym bardzo intrygującym materiałem jest wprowadzone w Indiach do produkcji jednorazowych sztućców połączenie prosa, pszenicy i ryżu. To właśnie 
z niego powstaje jadalna łyżka czy widelec, którymi możemy bez kłopotu zjeść nawet gorącą zupę. Mają one trzyletnią datę przydatności do użycia, miękną dopiero po spędzeniu około 30 minut w cieczy, a rozkładają się po 4-5 dniach. Na dodatek sztućce te produkowane są w wielu wariantach smakowych, na przykład: słodko-cukrowym, imbirowo-cynamonowym czy imbirowo-czosnkowym.

Firma Arbor Teas produkująca herbaty przez wiele lat udoskonalała wykorzystywane przez siebie opakowania, zaczynając od popularnych na rynku herbat stalowych puszek, następnie inwestując w opakowania papierowe, aż do odkrycia w pełni kompostowalnego materiału, jakim jest folia celulozowa wytwarzana z pulpy drzewnej. Pomimo znalezienia odpowiedniego materiału opakowaniowego przez długi czas firma ta poszukiwała właściwego rozwiązania do umieszczania etykiet na opakowaniach herbat. Z początku używała papierowych etykiet przyczepianych do paczki herbaty za pomocą gumek - to rozwiązanie nie satysfakcjonowało jednak w pełni właścicieli przedsiębiorstwa. Poszukując lepszej metody znakowania opakowań, natrafiono na firmę produkującą w 100\% kompostowalne etykiety wykonane z trzciny cukrowej lub z papieru z konopi, naklejane za pomocą wegańskiego biodegradowalnego i kompostowalnego kleju.

\section{Wnioski}

Z przytoczonych danych jednoznacznie wynika, że problem tworzyw sztucznych dotyka dzisiaj całego świata. Ludzie nie są jeszcze w pełni świadomi, że ich codzienne decyzje mają ogromny wpływ na stan środowiska naturalnego w przyszłości. Widać to na ulicach miast, w sklepach czy na plażach — ludzie notorycznie kupują torebki foliowe, piją z plastikowych kubków, używają słomek itp. Do produktów, które uważane są za największe zło, należą opakowania, a dokładniej odpady opakowaniowe oraz przedmioty jednorazowego użytku.

Możemy zaobserwować, że coraz częściej państwa przejmują odpowiedzialność za minimalizowanie negatywnych skutków korzystania $\mathrm{z}$ wszelakich produktów zawierających tworzywa sztuczne. Dokonują tego, tworząc akty prawne regulujące obrót i gospodarowanie takimi przedmiotami. W skrajnych przypadkach zabraniają produkowania danych towarów bądź nakładają surowe kary za ich używanie. Nawet Unia Europejska podjęła stanowcze kroki do ograniczenia niekorzystnych konsekwencji produkowania, używania i gospodarowania zużytymi produktami zawierającymi tworzywa sztuczne poprzez wydanie dyrektywy w sprawie zmniejszenia wpływu niektórych produktów z tworzyw sztucznych na środowisko. Wszystkie państwa członkowskie będą zobligowane do zastosowania się do wytycznych zawartych w tym dokumencie, przez co przewiduje się nieużycie ogromnej ilości plastiku w ciągu następnych lat.

Dodatkowo ludzie powoli zaczynają rozumieć wpływ swoich działań na kondycję naszej planety, co powoduje powstawanie wielu organizacji mających na 
celu zwiększenie wiedzy społeczeństwa w kwestii edukacji środowiskowej. Często organizacje te rozpoczynają różne akcje społeczne związane z konkretnymi zagadnieniami dotyczącymi ochrony środowiska. W Polsce jedną z najgłośniejszych kampanii jest „tu pijesz bez słomki”, która ma na celu zwrócenie uwagi ludzi na problem zanieczyszczenia wód. Akcja ta bardzo dobrze się przyjęła i w coraz większej liczbie pubów, restauracji czy barów odchodzi się od praktyki podawania słomek do napojów lub ewentualnie zamienia się zwykłe, plastikowe słomki na biodegradowalne.

Ostatecznie wiele produktów zawierających plastik zostaje zastąpionych lub może zostać zastąpionych dzięki wykorzystaniu alternatywnych materiałów do produkcji. Przedsiębiorcy dążą do opanowania możliwie najtańszych metod produkcji przedmiotów alternatywnych, tak aby produkt był biodegradowalny lub chociaż przyjazny dla środowiska.

Podsumowując, należy podkreślić, że nagłośnienie problemu tworzyw sztucznych skutkuje wieloma obostrzeniami prawnymi, które mają na celu zmobilizowanie podmiotów gospodarczych do zmniejszenia degradacji środowiska. Wpływa to również na postawy zakupowe klientów, pobudza ich ciekawość, co w konsekwencji prowadzi do edukowania się społeczeństwa w tej kwestii. Dzięki odpowiednim postawom zarówno producentów, jak i konsumentów można znacznie ograniczyć zużywanie plastiku, co wywrze pozytywny wpływ na środowisko naturalne w przyszłości.

\section{Bibliografia}

A Spoon You Can Eat Is a Tasty Alternative to Plastic Waste. Data dostępu: 10.11.2019, https://www. youtube.com/watch? $\mathrm{v}=\mathrm{r} 4 \mathrm{Cc} 5 \mathrm{zmy} 0 \mathrm{eY}$.

Bellon, M. (8.11.2018). Unijny zakaz plastiku to nie koniec świata. Sa alternatywy, a dostarczaja ich polskie firmy. Data dostępu: 21.08.2019, https://businessinsider.com.pl/firmy/przepisy/zakaz-plastiku-jakie-sa-alternatywy/zsn328m.

Butelki Coca-Coli z wyłowionego z morza przetworzonego plastiku (8.10.2019). Data dostępu: 10.10.2019, https://www.wirtualnemedia.pl/artykul/butelki-coca-coli-z-wylowionego-z-morza-przetworzonego-plastiku.

Czopyk, D. Czym jest zero waste. Data dostępu: 15.10.2019, http://zero-waste.pl/czym-jest-zero-waste/.

Deloitte Polska (22.01.2019). Sektor opakowań to branża, która w pierwszej kolejności będzie musiała znaleźć sposób na skuteczny recykling odpadów z plastiku. Data dostępu: 26.08.2019, https://www2.deloitte.com/pl/pl/pages/press-releases/articles/sektor-pakowan-skuteczny-recykling-produktow-z-plastiku.html.

Ekologia to nowy luksus - Chanel inwestuje w zielony start-up Sulapac (12.12.2018). Data dostępu: 10.10.2019, https://www.wiadomoscihandlowe.pl/artykuly/ekologia-to-nowy-luksus-chanel-inwestuje-w-zielony,51287.

Gospodarka o obiegu zamkniętym. Data dostępu: 30.09.2019, https://www.wwf.pl/ekonsumpcja/gospodarka-o-obiegu-zamknietym.

Hales, C.F. (1999). Opakowanie jako instrument marketingu, Warszawa: Polskie Wydawnictwo Ekonomiczne.

Ekonomia - Wroclaw Economic Review 26/1, 2020

(C) for this edition by CNS 
hasło: biodegradacja. W Encyklopedia PWN. Data dostępu: 10.07.2019, https://encyklopedia.pwn. $\mathrm{pl} /$ haslo/biodegradacja;3877794.html.

https://ec.europa.eu/.

https://torbacze.com/.

https://www.arborteas.com/compostable-packaging/.

https://www.kickstarter.com/projects/643319217/beleaf.

https://www.naturallychic.green/.

https://www.sulapac.com/about/.

Jachowicz, T. (24.05.2017). Powrót opakowań do natury - biodegradacja i biodegradowalność tworzyw. Data dostępu: 3.10.2019, https://www.kierunekspozywczy.pl/artykul,38280,powrot-opakowan-do-natury-biodegradacja-i-biodegradowalnosc-tworzyw.html.

Jadalna kropla wody. Czy to koniec plastikowych butelek? (14.04.2017). Data dostępu: 9.10.2019, https://www.tvp.info/29949459/jadalna-kropla-wody-czy-to-koniec-plastikowych-butelek.

Jadalne kulki wodne zrewolucjonizuja dystrybucję wody (14.04.2017). Data dostępu: 10.09.2019, https://joemonster.org/art/39402.

Kędzierska, J. (2.10.2019). Indie zakazuja sprzedaży jednorazowego plastiku. Data dostępu: 8.10.2019, https://www.green-news.pl/416-indie-zakaz-sprzedazy-jednorazowego-plastiku.

Kołodziej, E. (17.07.2018). Adidas dołacza do wojny przeciw plastikom i rozpoczyna rewolucję. Ich ubrania i buty będa w większości z recyklingu. Data dostępu: 16.10.2019, https://noizz. $\mathrm{pl} /$ fashion/adidas-rezygnuje-z-plastiku/chg4yvf?utm_source=noizz.pl_viasg_noizz\&utm _ medium=referal\&utm_campaign=leo_automatic\&srcc=ucs\&utm_v=2.

Odpady. Data dostępu: 21.09.2019, https://www.wwf.pl/ekonsumpcja/odpady.

Odpady z tworzyw sztucznych i recykling w UE: fakty i liczby (15.01.2019). Data dostępu: 21.09.2019, http://www.europarl.europa.eu/news/pl/headlines/society/20181212STO21610/odpady-z-tworzyw-sztucznych-i-recykling-w-ue-fakty-i-liczby.

PAP (6.03.2019). Co roku do oceanu trafia 8 milionów ton plastiku. Za 30 lat będzie go więcej niż ryb. Data dostępu: 15.07.2019, https://www.tvp.info/41621193/co-roku-do-oceanu-trafia-8-milionow-ton-plastiku-za-30-lat-bedzie-go-wiecej-niz-ryb.

PAP (28.08.2017). Więzienie lub wysoka grzywna za... plastikowe torebki. Restrykcyjne przepisy w Kenii. Data dostępu: 8.10.2019, https://wpolityce.pl/lifestyle/355099-wiezienie-lub-wysoka-grzywna-za-plastikowe-torebki-restrykcyjne-przepisy-w-kenii.

Parlament Europejski i Rada UE (12.06.2019). Dyrektywa 2019/904 z dnia 5 czerwca 2019 r. w sprawie zmniejszenia wpływu niektórych produktów z tworzyw sztucznych na środowisko, Dz.U. UE, L 155.

Parlament Europejski popart wprowadzenie do 2021 r. zakazu sprzedaży plastikowych jednorazówek (27.03.2019). Data dostępu: 9.10.2019, https://www.europarl.europa.eu/news/pl/press-room/20190321IPR32111/parlament-poparl-wprowadzenie-do-2021-r-zakazu-plastikowych-jednorazowek.

Piątka za segregację - rusza kampania edukacyjna Ministerstwa Środowiska dot. segregacji odpadów (23.10.2019). Data dostępu: 25.10.2019, https://www.gov.pl/web/srodowisko/piatka-za-segregacje--rusza-kampania-edukacyjna-ministerstwa-srodowiska-dot-segregacji-odpadow.

Plastikowe talerze i stomki będa zakazane w UE od 2021 roku (21.05.2019). Data dostępu: 9.10.2019, https://polskieradio24.pl/5/1223/Artykul/2312685,Plastikowe-talerze-i-slomki-beda-zakazane-w-UE-od-2021-roku.

Sojkin, B. (red.) (2003). Zarzadzanie produktem. Warszawa: Polskie Wydawnictwo Ekonomiczne.

Strzałkowski M. (11.10.2018). PE chce wycofania jednorazowych plastikowych produktów od 2021 r. Data dostępu: 25.07.2019, https://www.euractiv.pl/section/energia-i-srodowisko/news/ pe-chce-wycofania-jednorazowych-plastikowych-produktow-od-2021-r/.

Szymczak, J., Ankiel-Homa, M. (2007). Opakowanie jednostkowe w działaniach marketingowych przedsiębiorstw. Poznań: Akademia Ekonomiczna w Poznaniu.

Ekonomia - Wroclaw Economic Review 26/1, 2020

(C) for this edition by CNS 
Traczyk, B. (2.08.2019). Gospodarka o obiegu zamkniętym. Data dostępu: 21.10.2019, https://www. gov.pl/web/srodowisko/goz.

Tu pijesz bez słomki. Data dostępu: 5.10.2019, https://noizz.pl/bezslomki.

Tworzymy innowacyjne produkty z otrąb pszennych (2016). Data dostępu: 21.08.2019, http://biotrem.pl/pl/.

Uryniuk, J. (5.10.2019). Jak zrezygnować z szamponu w plastikowych butelkach? Można go zastapić szamponem w kostce. Data dostępu: 8.10.2019, https://www.green-news.pl/428-jak-zrezygnowac-z-szamponu-w-plastikowej-butelce.

Ustawa z dnia 13 czerwca 2013 r. o gospodarce opakowaniami i odpadami opakowaniowymi, Dz.U. z 2013 r. poz. 888.

W Polsce zużywa się 3,5 mln ton plastiku rocznie (23.01.2019). Data dostępu: 5.10.2019, https:// strefabiznesu.pl/w-polsce-zuzywa-sie-35-mln-ton-plastiku-rocznie/ar/c3-13830704. 